\section{Erratum}

Check for updates

\title{
Erratum: Special Articles for Korean History of Infectious Diseases
}

- This corrects the article "History of Tsutsugamushi Disease in Korea" in volume 51 on page 196.

- This corrects the article "History of Syphilis and Gonorrhea in Korea" in volume 51 on page 210.

- This corrects the article "Historical Review of Leptospirosis in the Korea (1945 - 2015)" in volume 51 on page 315.

- This corrects the article "Management of Typhoid Fever ? Clinical and Historical Perspectives in Korea" in volume 51 on page 330.

- This corrects the article "Hemorrhagic Fever with Renal Syndrome" in volume 51 on page 405.

- This corrects the article "Modern History of Tuberculosis in Korea" in volume 51 on page 414.

- This corrects the article "Cholera Outbreaks in Korea after the Liberation in 1945: Clinical and Epidemiological Characteristics" in volume 51 on page 427.

- This corrects the article "Review of Measles in Korea: Quarantine and Elimination" in volume 52 on page 113.

- This corrects the article "History and Epidemiology of Bacillary Dysentery in Korea: from Korean War to 2017" in volume 52 on page 123.

We found error in our published articles.

Copyright $\odot 2020$ by The Korean Society of Infectious Diseases, Korean Society for Antimicrobial Therapy, and The Korean Society for AIDS

This is an Open Access article distributed under the terms of the Creative Commons Attribution Non-Commercial License (https:// creativecommons.org/licenses/by-nc/4.0/) which permits unrestricted non-commercial use, distribution, and reproduction in any medium, provided the original work is properly cited.
The 9 articles published between 2019 Jun;51(2) to 2020 Mar;52(1), below are the secondary publications of 'Korean Society of Infectious Disease (KSID). History of Infectious Disases II. Seoul: Koonja; 2018. (ISBN 979-11-5955-379-0)', but these are not specified.

- Chung MH, Kang JS. History of Tsutsugamushi Disease in Korea. 2019 Jun;51(2):196-209. https://doi.org/10.3947/ic.2019.51.2.196

- Choi JK, Lee SJ, Yoo JH. History of Syphilis and Gonorrhea in Korea. Infect Chemother. 2019 Jun;51(2):210-216. https://doi.org/10.3947/ic.2019.51.2.210

- Kim MJ. Historical Review of Leptospirosis in the Korea (1945 - 2015). Infect Chemother. 2019 Sep;51(3):315-329. https://doi.org/10.3947/ic.2019.51.3.315

- Chang MS, Woo JH, Kim S. Management of Typhoid Fever - Clinical and Historical Perspectives in Korea. Infect Chemother. 2019 Sep;51(3):330-335. https://doi.org/10.3947/ ic.2019.51.3.330

- Noh JY, Jung J, Song JW. Hemorrhagic Fever with Renal Syndrome. Infect Chemother. 2019 Dec;51(4):405-413. https://doi.org/10.3947/ic.2019.51.4.405

- Song JH, Huh K, Chung DR. Modern History of Tuberculosis in Korea. Infect Chemother. 2019 Dec;51(4):414-426. https://doi.org/10.3947/ic.2019.51.4.414 
- Kim YS. Cholera Outbreaks in Korea after the Liberation in 1945: Clinical and Epidemiological Characteristics. Infect Chemother. 2019 Dec;51(4):427-434. https://doi. org/10.3947/ic.2019.51.4.427

- Kang JH. Review of Measles in Korea: Quarantine and Elimination. Infect Chemother. 2020 Mar;52(1):113-122. https://doi.org/10.3947/ic.2020.52.1.113

- Pai H. History and Epidemiology of Bacillary Dysentery in Korea: from Korean War to 2017. Infect Chemother. 2020 Mar;52(1):123-131. https://doi.org/10.3947/ic.2020.52.1.123

We apologize for any inconvenience that it may have caused. 